\title{
TEACHERS' EFFECTIVENESS AT CHANGING PUPILS' ATTITUDES TOWARDS MIGRANTS: A FIELD STUDY IN ITALY AND RUSSIA
}

\author{
L. BOMBIERI ${ }^{\mathrm{a}, \mathrm{b}}$, V.N. GALYAPINA ${ }^{\mathrm{b}}$, E.V. BUSHINA \\ ${ }^{a}$ Italian Ministry of Education (Padua, Italy) \\ ${ }^{b}$ National Research University Higher School of Economics, 20 Myasnitskaya Str., Moscow, 101000, \\ Russian Federation
}

\begin{abstract}
In this study we examined whether different styles of teachers' instructions (pro-social vs behavioural) affect the attitudes and beliefs of pre-adolescents towards peers with migrant backgrounds. The research was conducted in two countries: in Italy $(\mathrm{N}=93)$ and in Russia $(\mathrm{N}=134)$ among students in their last year of primary school $(\mathrm{M}$ age $=11.27)$. Teachers provided one in two sets of instructions, highlighting either the welcoming and openness characteristics of the group or its adherence to school-norms. After receiving this recommendation, pupils read a fictional scenario depicting a fellow student from an undisclosed foreign country, with different cultural features, and who was expected to join that class-group. Children's opinions were measured through five scales addressing the newcomer's pleasantness, positive and negative attitudes towards the respondents' (ingroup) and the newcomer's group of friends (outgroup). On an individual level, results confirm that pro-social instructions enhance positive traits towards the unknown student at a higher extent. A significant difference was also reported when comparing the two conditions on a group level: favourable characteristics were more prominent in the prosocial condition than in the behavioural one and negative traits, both in the in-group's and outgroup's projections, were reduced. We discuss the implications of these results with regard to teachers' impact in modelling social skills and the development of social processes in the school context.
\end{abstract}

Keywords: attitude towards migrants, newcomer, pro-social vs behavioural instructions, in-group and out-group attitudes.

\section{Introduction}

Migration floods have dramatically increased in frequency and numbers over the past two decades. The phenomenon is continually changing in characteristics and populations affected by it (Eurostat, 2017). The challenges they are posing are 
also evolving, and they demand a difficult shift in host communities. Many spheres within the social structure are struggling to find effective strategies and policies to balance needs of the local population and those of immigrants who moved pursuing better life conditions for themselves and their families.

An important effect of this global challenge is the higher number of children with migration background living in countries that are not their own, meeting a lot of difficulties socializing in such new conditions. One crucial field of interaction between local people and newcomers is schooling. Most migrant families must cope with their offsprings' need for education and that means being involved in a host school system. In this specific context, and for the purpose of the study, teachers assume a pivotal role in modulating and stimulating behavioural outcomes among children.

\section{Categorisation and prejudice}

In their study on "New Racism" (Verkuyten \& Masson, 1995), the authors highlighted the different meaning that ethnic prejudice assumes for a minority or majority population. While it can be seen as a cognitive boundary essential to protect their own cultural identity among the first group, for the host community it may uphold a feeling of superiority and in-group belonging. Verkuyten and colleagues investigated different age groups, and they suggested that preadolescence can be considered particularly vulnerable to prejudice formation because of important socio-cognitive developments that happen at this age. Children are increasingly aware of social group norms and of ethnicity as a dimension for group evaluation, and tend to unquestioningly trust those categories (Thijs \& Verkuyten, 2016).

Further, Aboud (2003) identified four statements that accounted for changes in prejudice acquisition in young children. First, she considered age changes, and parents' and peers' influence. Second, two more mediators were included: the selfgroup-individual focus and affect-perception-cognition. In her studies, she then discriminated between egocentrism which is considered a strong bias on the self, and sociocentrism as a tendency to systematically favour a child's own group. This progression happens throughout daily interactions that children experience with significant adults, sometimes dealing with mixed, if not plainly opposite, inputs and feedback.

Finally, in his Developmental Social Identity Theory of Prejudice, Nesdale (2004) offered a model which provides a progression in four sequential development phases, namely "undifferentiated", "ethnic awareness", "ethnic preference", and "ethnic prejudice". When children acquire a stable ethnic self-identity approximately at the age of 7, they express more in-group preferences and biases rather than dislike towards the out-group. This is particularly true for children belonging to the dominant group. However, children belonging to a minority group can often observe rejection for their in-group in favour of the culturally dominant out-group. Almost at the same time, part of the population of children are not merely focusing on the in-group's positive differentiation from the out-group, but they are equally concerned about the out-group. "Instead of liking an out-group member less than 
an in-group member, prejudice means that out-group members are disliked or hated" (Nesdale, 2004, p. 6).

Based on these converging results, the sample for this study will be selected among students in their final year of primary school, due to their expected level of maturity in global development, education and ethnic identity awareness.

\section{Prejudice reduction}

Another important theory, which adds information and strategies when tackling these issues, is the Intergroup Contact Hypothesis (Allport, 1954) to resolve prejudice and enhance cooperation. It was further developed to include several constructs and it was encoded as a larger theory starting in the nineties. In his article, Pettigrew (1998) investigated four different strategies for prejudice reduction through learning about the out-group, changing behaviour, generating affective ties, intergroup reappraisal. Thus, at the end of the same article, he outlined several examples of how societies are partially responsible for shaping contact effects. "[These] societal contexts severely limit all forms of intergroup contact. Moreover, they render the contact that does occur less than optimal (...)” (p. 78).

Even though this theory and all its expansions have shown major limitations, "[...] cross-group contact is an essential, if insufficient, component for lasting remedies. Strict segregation between groups, limiting positive intergroup contact, has failed around the globe." (Pettigrew, Tropp, Wagner, \& Christ, 2011, p. 278). Under appropriate conditions, interpersonal contact is still one of the most effective ways to reduce prejudice between majority and minority group members (Allport, 1954; Stephan \& Stephan, 2000).

Supported by these results, the vignette used for the study was worded to introduce a foreseeable meeting between participants and the fictional foreign character, so to make this contact plausible and meaningful.

\section{Teachers' modelling and students' imitative learning}

The core nature of imitative learning is intrinsically perceptual-motor, but it also includes abstract sociocultural knowledge that induces imitation (Losin et al., 2015). Children are more likely to generalize observed types of behaviour when they witness a positive and desirable outcome. They are also selective in whom they decide to copy (Boyd \& Richerson, 1985). The imitative learning process, then, should be considered in its multiple layers of cognitive, adaptive, social and individual components. For these authors, all these learning processes require a high level of metacognition, because the focus is primarily on social learning from knowledgeable agents: skills required to make such decisions are so precise that they encourage blind, high-fidelity copying (a key requirement for cumulative cultural change).

More specifically, the role of teachers when modelling cognitive processes and behavioural outcomes is widely investigated with consistent results (Keene \& Zimmermann, 2013; Montague, Krawec, Enders, \& Dietz, 2014). The positive 
effect of such insroletruction and expectations has been found using several measurements: literacy development, successful test outcomes, and metacognition, just to mention a few. While teachers' impact on value transmission is not so univocal and well-known, it is still considered to exert an implicit influence. Several surveys aimed at teenagers found that the main explicit models are family members and peers with little to no mention of teachers and educators. Nonetheless, a few studies have attempted to gather evidence concerning the transmission of values through teachers (van Oudenhoven, Blank, Leemhuis, Pomp, \& Sluis, 2008; Fallona, 2000), with promising but still indecisive findings.

For these reasons, one of the goals of this study is to test whether the teachers' favourable impact on children can be measured through pro-social outcomes, such as enhancing beliefs and opinions towards a newcomer with a migrant background.

\section{The present study}

\section{Sociocultural context}

Italy and Russia were chosen due to some similarities both in their school organization and demographics.

Regarding the former, teachers are expected to exert similar outcomes in both countries due to their key position in pupils' school life. Both in Italy and in Russia, in fact, each group-class can clearly identify few role-modelling persons, considering that some practitioners are spending a larger amount of time with them than other specialists. Moreover, those people do not only teach core subjects (such as the national language, Maths, History, etc.) but they perform other caring duties, sharing meals and school trips, dealing with discipline, and implementing a fruitful collaboration with the families.

As for the latter, referring to a report published by the United Nations (http://www.un.org/en/development/desa/population/migration/data/estimates2/data/UN_MigrantStockTotal_2017.xlsx), the number of migrants in the countries is twice as much in Russia as in Italy (11.6 million versus 6 million), but it is compensated by the fact that the global population has also doubled. When considering the repercussions for the schools, the raw statistics show that Italy counts $20 \%$ of migrants aged $6-16$ on its territory while Russia has $11 \%$ of them. This gap, however, doesn't account for the variety of ethnic diversities within the Russian Federation, where, on the one hand, some countries have shared and preserved a common background even after achieving an independent status in recent times while others are still formally citizens even though they have maintained and developed separate languages and traditions. In a study on migrant students in Saint Petersburg, Alexandrov, Baranova and Ivaniushina (2012) noted that, from a school's point of view, linguistic and cultural differences are much more important than citizenship. "Russian-speaking migrants from Belarus and Ukraine, although not citizens of Russia, are not thought of as migrants by the teachers, whereas arrivals from Chechnya or Dagestan which are parts of Russian Federation are considered migrants" (p. 7). 
In summary, this research aims at examining the relationships between teachers' instruction and changes in attitudes and stereotypes towards migrants with unspecified backgrounds within the mainstream student population.

The study was carried out in two countries but the main calculations and comparisons were done on the whole sample. It is expected that teachers' own explicit expectations will affect how pupils react to a newcomer: the more inclusive is the priming received from teachers, the more well-disposed the children will be. Stereotypes and attitudes are also assumed to be similar in consideration to the country: notwithstanding discernible incongruences, the experience that students have in interacting with foreigners seem comparable in size and variety.

Thus, the goal of the study is to reveal the role of teacher's instruction at changing attitudes with a general hypothesis stating that teachers' pro-social instructions should promote more positive attitudes among majority pupils toward a newcomer than behavioural instructions.

More specifically, it will be investigated whether:

H1. Pro-social instruction increases the likeability towards newcomers as individuals;

H2. Pro-social instruction raises positive attitudes towards both the ingroup and the out-group;

H3. Pro-social instruction reduces negative attitudes towards both the ingroup and the out-group.

\section{Method}

\section{Sample}

Data was collected from three schools in Northern Italy (in the outskirts of Milan, in Ravarino - Modena, and in Padua) and in five schools in Russia, three in Moscow and two in the nearby region (Zvenigorod and Peredelkino). In both countries there was a combination of rural and urban backgrounds.

The participants were children in their last year of primary school. Teachers were trained to give pro-social and behavioural instruction to pupils. The total number of children involved was 216 in Russia and 119 in Italy. After screening for missing values, 134 completed questionnaires from respondents from Russia (59 males) and 93 from Italy (46 males) were retained.

The age group has been controlled by the researchers, so the two groups do not differ significantly on that count between them $(\mathrm{M}=11.27)$.

Among the Russian participants, two thirds (98) recognised themselves as Russian because both their parents were Russian citizens. Similarly, 62 participants identified themselves as Italian. It is also worth noting that 12 Russian and 16 Italians selected the option "double nationality" with only one parent (or none) from the mainstream national group. When considering the countries of immigration, it should be noted that the list only partially overlaps. The two largest groups in Russia comprised Ukrainians (12) and Koreans (11), while in Italy it included Ukrainians (16) and Chinese (9) people. A total of 27 countries were represented 
at least once in either of the two populations, ranging from South America to far Eastern Asian countries and North/Central Africa.

\section{Measures}

The survey booklet included a first page with general demographic information, the manipulation check, a short text of about 145 words with the description of the newcomer and 3 cohorts of questions addressing 5 scales.

In the text, pupils became acquainted with a perspective new classmate whose main feature was to be a recent migrant. In the story a few elements were considered and selected. First of all, gender and age matched those of the respondents and every reference to a peculiar national background was attentively avoided. Consequently, the name (Yori) was also neutral. A blurred family background is mentioned. An excerpt of this section reads: "He/She lives with his/her family. His/Her father is a farmer. [...] His/Her mother is very patient [...]. She works a few hours every day, and then does the house chores. He/She [...] loves tagging along his/her friends. Yori has a sister/brother. She/He is younger and they get along well with each other. They have a cow." Secondly, it is mentioned that the decision to leave their country of origin is due to contextual reasons: "Life is difficult for Yori's family and so his/her parents have decided to leave their country." Thirdly, it is stated that the student will soon join the respondents' class group: "Yori will be in your class when he/she relocates." At the end, several basic differences are listed, to create a cultural distance between the new student and the host community: "He/She doesn't speak your language. His/her alphabet is different as well. In his/her country clothes are a bit different: he/she has never worn a pair of jeans, for example."

Following the vignette, pupils found questions investigating their attitudes and beliefs towards the individual fellow student and the two groups as a whole, their own and Yori's.

Newcomer's Likeability was assessed through ten short statements measuring how positively the coming fellow student was anticipated. Each item was rated using a 6-point scale ranging from "very strongly disagree"(1) to "very strongly agree" (6). A higher score indicated a more favourable expectation and attitude toward the unknown peer. These items were retrieved in Reysen (2005). Sample items are "Yori is friendly", "I would like to ask Yori for advice", "I would like Yori as a team member", and "I would like to be friends with Yori". Other six characteristics matching the first structure were likeable, warm, approachable, physical attractive, similar to me and knowledgeable. Cronbach's $\alpha$ for Likeability scale is .82 , and CFA indicators are $\chi^{2} / \mathrm{df}=1.47, \mathrm{CFI}=.9, \mathrm{RMSEA}=.05, \mathrm{PCLOSE}=.57$.

Stereotypes towards the in-group and the out-group were measured using Multi-response Racial Attitude Scale (Doyle \& Aboud, 1995). Each item included the target word and a brief description of a behavioural example, such as "Clean never forgets to wash hands before eating" or "Unfriendly - always pushing others around and getting into fights". Participants were asked to indicate whether they thought these characteristics applied to members in their group of friends or in the 
newcomer's. Each item was rated using a 5-point scale ranging from 'all' (1) to 'none' (5). The instructions were formulated as "In my opinion, __ my friends are: " and "In my opinion, ___ Yori's friends are:__. The values were reversed so $\overline{\text { that }}$ higher scores indicated a higher attribution both in the positive and in the negative spheres. The eight adjectives forming the In-group-positive (In-grouppos) and the Out-group-positive (Out-group-pos) scales are clean, healthy, nice, happy, friendly, kind, helpful, and smart. The In-group-pos subscale has a $\alpha=.72$ and $\chi^{2} / \mathrm{df}=2.01$; CFI $=.96$; RMSEA $=.07$; PCLOSE $=.18$; the Out-group-pos subscale has a $\alpha=.73$ and $\chi^{2} / \mathrm{df}=2.11$; CFI=.98; $\mathrm{RMSEA}=.07$; PCLOSE $=.14$.

The seven adjectives included in the In-group-negative (In-group-neg) and the Out-group-negative (Out-group-neg) scales are unfriendly, mean, dirty, stupid, selfish, sick, and naughty. The In-group-neg subscale has a $\alpha=.75$ and $\chi^{2} / \mathrm{df}=1,14$; $\mathrm{CFI}=.99 ; \mathrm{RMSEA}=.03 ; \mathrm{PCLOSE}=.70$; the Out-group-neg subscale has a $\alpha=.75$ and $\chi^{2} / \mathrm{df}=2.35 ; \mathrm{CFI}=.98 ; \mathrm{RMSEA}=.08 ; \mathrm{PCLOSE}=.12$.

\section{Procedure}

Prior to data collection, the researchers have obtained Ethical Approval from the home institution and individual consents from parents of the minors involved.

The session covered one academic hour $\left(45^{\prime}\right)$ and was performed during regular school time and with the contribution of (one of) the main teachers for each class.

At first, the teachers guided the students through the demographic section and the training questions.

Then the teacher delivered the news that a new student (without any specification about gender or provenience) was going to join their class-group and two sets of instructions were used to prime the expected behaviour from the pupils. In the experimental condition (pro-social), it was reminded that "in our class we are always glad to meet new people, to know each other better and to include everybody with their similarities and differences". In the control condition, behavioural rules were made salient, stating that "in our class we sit nicely, are always on time for classes, do not run in the corridor and the same rules apply to everybody".

\section{Results}

After performing the preliminary screening to identify which questionnaires could be retained as valid, it was calculated the overall means and standard deviations for each scale (Table 1).

To test our first hypothesis whether the teacher's instructions contributed to pupils' attitudes towards the newcomer, we performed MANCOVA with instructions as an independent variable and Newcomer's Likeability, In-group and Outgroup positive attitudes, In-group and Out-group negative attitudes as dependent variables. The analysis showed a significant multivariate main effect: Wilks' $\lambda=.897$, $F(5,221)=5.068, p<.001, \eta^{2}=.103$. ANCOVAs on the individual measures were significant for all the scales (see Table 2). 
Descriptive Statistics (Whole Sample)

\begin{tabular}{|l|c|c|c|}
\hline \multicolumn{1}{|c|}{ Scale } & N & M & SD \\
\hline Newcomer's Likeability & 227 & 4.17 & 0.86 \\
\hline In-group-pos & 227 & 3.36 & 0.69 \\
\hline In-group-neg & 227 & 2.59 & 0.84 \\
\hline Out-group-pos & 227 & 3.42 & 0.77 \\
\hline Out-group-neg & 227 & 2.76 & 0.83 \\
\hline
\end{tabular}

Note. The Newcomer's likeability scale is measured on a 6-point scale and the M lies above the average point; In-group and Out-group scales are all measured on a 5-point scales and both the positive means are above average while both the negative means are average.

Table 2

Instructions' Means for Newcomer's Likeability, In-group-pos, In-group-neg, Out-group-pos, Out-group-neg $(\mathrm{N}=227)$

\begin{tabular}{|l|c|c|c|c|}
\hline \multirow{2}{*}{\multicolumn{1}{c|}{ Scale }} & Pro-social & Behavioural & \multirow{2}{*}{ F(1, 225) } & \multirow{2}{*}{ Partial $\boldsymbol{\eta}^{2}$} \\
\cline { 2 - 3 } & $\mathrm{M}(\mathrm{SD})$ & $\mathrm{M}(\mathrm{SD})$ & & \\
\hline 1. Newcomer's Likeability & $4.39(0.80)$ & $3.96(0.86)$ & 14.921 & $.062^{* * *}$ \\
\hline 2. In-group-pos & $3.51(0.72)$ & $3.22(0.63)$ & 9.948 & $.042^{* *}$ \\
\hline 3. In-group-neg & $2.41(0.83)$ & $2.76(0.82)$ & 10.094 & $.043^{* *}$ \\
\hline 4. Out-group-pos & $3.59(0.76)$ & $3.25(0.74)$ & 11.657 & $.049^{* * *}$ \\
\hline 5. Out-group-neg & $2.62(0.81)$ & $2.89(0.83)$ & 6.247 & $.027^{*}$ \\
\hline
\end{tabular}

${ }^{*} p<0.05,{ }^{* *} p<0.01,{ }^{* * *} p<0.001$.

Note. The Newcomer's likeability scale is measured on a 6-point scale and the M lies above the average point; In-group and Out-group scales are all measured on a 5-point scales and both the positive means are above average while both the negative means are average.

In the condition of pro-social instructions, students expressed higher scores towards the newcomer as an individual. Moreover, they indicated more positive attitudes both towards the in-group and the out-group. When exposed to behavioural instructions, negative attitudes towards the in-group and the out-group were significantly higher in comparison with pro-social instructions.

The possible effect of gender was checked, but no significant difference between boys and girls was shown across all the scales (Table 3 ).

Furthermore, correlational analysis was performed (Table 4). Results showed that Newcomer's Likeability is positively correlated with positive attitudes towards the in-group and the out-group and negatively correlated with negative attitudes towards the in-group and the out-group.

To investigate the impact of teacher's instruction on the general perception of the newcomer and the two groups, we performed another correlational analysis 
Table 3

Gender's Means for Newcomer's Likeability, In-group-pos, In-group-neg, Out-group-pos, Out-group-neg $(\mathrm{N}=227)$

\begin{tabular}{|l|c|c|c|c|}
\hline \multirow{2}{*}{\multicolumn{1}{c|}{ Scale }} & Males & Females & \multirow{2}{*}{ F(1, 225) } & \multirow{2}{*}{ Partial $\boldsymbol{\eta}^{2}$} \\
\cline { 2 - 3 } & $\mathrm{M}(\mathrm{SD})$ & $\mathrm{M}(\mathrm{SD})$ & & .007 \\
\hline 1. Newcomer's Likeability & $4.09(0.80)$ & $4.24(0.91)$ & 1.614 & .002 \\
\hline 2. In-group-pos & $3.39(0.69)$ & $3.33(0.70)$ & 0.419 & .000 \\
\hline 3. In-group-neg & $2.60(0.87)$ & $2.59(0.83)$ & 0.004 & .002 \\
\hline 4. Out-group-pos & $3.45(0.78)$ & $3.38(0.75)$ & 0.482 & .001 \\
\hline 5. Out-group-neg & $2.78(0.90)$ & $2.74(0.77)$ & 0.147 & \\
\hline
\end{tabular}

Note. The Newcomer's likeability scale is measured on a 6-point scale and the M lies above the average point; In-group and Out-group scales are all measured on a 5-point scales and both the positive means are above average while both the negative means are average.

Table 4

Newcomer's Likeability, In-group-pos, In-group-neg, Out-group-pos, and Out-group-neg Whole Sample Correlations $(\mathrm{N}=227)$

\begin{tabular}{|l|c|c|c|c|}
\hline \multicolumn{1}{|c|}{ Variables } & $\mathbf{1}$ & $\mathbf{2}$ & $\mathbf{3}$ & $\mathbf{4}$ \\
\hline 1. Newcomer's Likeability & - & & & \\
\hline 2. In-group-pos & $.375^{* * *}$ & - & & \\
\hline 3. In-group-neg & $-.226^{* * *}$ & $-.401^{* * *}$ & - & \\
\hline 4. Out-group-pos & $.397^{* * *}$ & $.479^{* * *}$ & $-.200^{* *}$ & - \\
\hline 5. Out-group-neg & $-.295^{* * *}$ & $-.387^{* * *}$ & $.661^{* * *}$ & $-.424^{* * *}$ \\
\hline
\end{tabular}

${ }^{* *} p<.01,{ }^{* * *} p<.001$.

separating the two conditions. In Tables 5 and 6 the results of such analyses are shown.

The results point to the fact that in the experimental (pro-social) condition the scores mirror the findings of the global sample. On the opposite, when we look at the behavioural instructions, the in-group and out-group negative correlations with the Newcomer's likeability scale were no longer significant. More specifically, the new member's positive attitude was positively related to both the in-group and the out-group positive perception but not related to the negative spectrum for each group. 
Newcomer's Likeability, In-group-pos, In-group-neg, Out-group-pos, and Out-group-neg Pro-social Instruction Correlations $(N=109)$

\begin{tabular}{|l|c|c|c|c|}
\hline \multicolumn{1}{|c|}{ Variables } & $\mathbf{1}$ & $\mathbf{2}$ & $\mathbf{3}$ & $\mathbf{4}$ \\
\hline 1. Newcomer's Likeability & - & & & \\
\hline 2. In-group-pos & $.401^{* * *}$ & - & & \\
\hline 3. In-group-neg & $-.276^{* *}$ & $-.484^{* * *}$ & - & \\
\hline 4. Out-group-pos & $.396^{* * *}$ & $.393^{* * *}$ & $-.322^{* * *}$ & - \\
\hline 5. Out-group-neg & $-.397^{* * *}$ & $-.472^{* * *}$ & $.685^{* * *}$ & $-.554^{* * *}$ \\
\hline
\end{tabular}

${ }^{* *} p<.01,{ }^{* * *} p<.001$.

Table 6

Newcomer's Likeability, In-group-pos, In-group-neg, Out-group-pos, and Out-group-neg Behavioural Instruction Correlations ( $N=118)$

\begin{tabular}{|l|c|c|c|c|}
\hline \multicolumn{1}{|c|}{ Variables } & $\mathbf{1}$ & $\mathbf{2}$ & $\mathbf{3}$ & $\mathbf{4}$ \\
\hline 1. Newcomer's Likeability & - & & & \\
\hline 2. In-group-pos & $.287^{* *}$ & - & & \\
\hline 3. In-group-neg & -.106 & $-.261^{* *}$ & - & \\
\hline 4. Out-group-pos & $.334^{* * *}$ & $.521^{* * *}$ & -.009 & - \\
\hline 5. Out-group-neg & -.156 & $-.258^{* *}$ & $.618^{* * *}$ & $-.265^{* *}$ \\
\hline
\end{tabular}

$* * * p<0.001$.

\section{Discussion}

The results presented so far support the leading hypothesis advanced for this study.

With regard to the general assumption that receiving pro-social instruction should promote more positive attitudes among the majority pupils toward a newcomer, all the findings are converging and consistently reinforcing a quite noticeable effect of the teachers' influence.

In more detail, the performed analyses dig further into several layers in order to highlight how students reacted in the two conditions of pro-social versus behavioural instruction.

Firstly, it was checked whether the new pupil would elicit a generally positive reception as an individual. Important to note, the gender of respondents did not affect any of these results. While already in the whole sample the average assessment falls within the top range, thus above the mean, it is when a comparison between the two conditions is performed that the role of the instruction shows significant differences. The behavioural set acts as a baseline, so it comes as no surprise 
that students are choosing the middle. When invited to be open and welcoming, students indicated a higher level of friendliness and kindness. According to the literature previously discussed, it is expected that the introduction of an unknown child as a future member of the in-group gives rise to a foreseeable alliance. In other words, it increases the cohesion within the group and reduces the distance with the newcomer's culture to accommodate all the members. Making salient a special aspect of being a member in that class-group activates a self-categorization process that recognises the new member as a good fit (Turner, Hogg, Oakes, Reicher, \& Wetherell, 1987). Furthermore, the main assumption within Allport's Hypothesis of Contact suggests that a decreased distance between groups with similar status can conversely help to reduce prejudice and, therefore, the new member of the group was seen with both curiosity and positive expectations (Binder et al., 2009; Stephan \& Stephan, 2001). Therefore, the first hypothesis has been fully confirmed.

Secondly, moving from the individual level to the group dimension, it was postulated that a pro-social set of instructions would enhance a more favourable perspective on the two groups as a whole, both regarding the respondent's circle of friends and the fictional newcomer's. Again, in the control (behavioural) condition the appraisal was still globally upward, above the mean, both for the in-group and the out-group; similarly, in the experimental (pro-social) condition, a pattern similar to the one described for the individual can be seen. Students expressed betterdisposed beliefs both towards their network and the new pupil's. It is arguable that the positive evaluation of the in-group could be a reflection of favouritism or bias. Being both groups seen as positively connotated, it seems more appropriate to look for an explanation into Collective Efficacy Theory (Bandura, 2000): the increase in desirable characteristics among the other members of the in-group can be seen as a reflection that this group is able to achieve a given task, namely, being socially welldisposed towards an unknown person who has been explicitly endorsed by the "authority" (Hughes, Cavell, \& Willson, 2001). Moreover, when observing the trait connotation of the out-group, the effect of a projection process can be recognized (Crisp \& Turner, 2009). If a positive contact can make relevant out-group members seem more similar to self, which we know is the case for actual and extended contact (Eller \& Abrams, 2004; Wright, Aron, McLaughlin-Volpe, \& Ropp, 1997), then those out-group members should benefit from the positive projection that ingroup members typically benefit from (Robbins \& Krueger, 2005). Consequently, the second hypothesis has also been fully supported.

Thirdly, it was observed whether the given instructions could influence the perception of negative traits, both in the in-group and in the out-group members.

As expected, the sample as a whole tended to increase the out-group undesirable characteristics more when compared to the in-group. Nevertheless, even though in the control group the students rated both groups as neither good nor bad, in the pro-social condition they moved the general estimation towards the better end of the continuum. The relative low level of stigma in both conditions can be referred to the general atmosphere that students perceive at school, more supportive and less judgemental than in the following grades. A positive school climate leads to 
serene pupils' relationships with peers and teachers and it simultaneously decreases other types of problems, i.e. behavioural (Thomas, Bierman, Powers, \& Conduct Problems Prevention Research Group, 2011). Having daily interaction with students from different backgrounds in real life could certainly help reduce the level of uncertainty when anticipating a newcomer, even in case of an unclear origin. Our findings are in line with the results of previous studies and reflect the idea that cultural diversity largely contributes to the creation of a peaceful social climate (Schachner, Noack, Van de Vijver, \& Eckstein, 2016; Civitillo et al., 2017). Thus, the third hypothesis has been confirmed as well.

It is worth mentioning that an unexpected result was found.

Correlations in the full sample follow a predictable sequence: observing the relations between the individual and the group scales presents positive correlations for positive items and a reverse pattern for negative items. According to the goal of this study, another comparison between the two manipulations has also been carried out. The previous outcome is mirrored in the condition of pro-social instructions, with a significant negative correlation between the individual level and the group scales measuring negative beliefs. In the control condition, however, this effect totally disappears, and those scales are responding only to their counterparts on the group level.

This finding can be considered supplementary evidence that the teacher's priming mark enforces cognitive and social changes beyond the mean comparisons: its echo is self-evident in the lack of an important link between the single and the collective level, both present in the general sample and in the experimental condition.

In conclusion, it seems that the class-group is a powerful aggregator that overcomes individual differences and helps to create a diffuse sense of "we" between all the members. Murray and Greenberg (2000) offered empirical support to the importance of a positive social and emotional adjustment for educational success in similar age-groups. The bond with teachers and the quality of peer-relations are crucial for reaching an optimal environment where to thrive and develop. Therefore, students are more sensitive to establish solid and fruitful relations with both the peers and the adults with whom they interact daily.

\section{Limitations and conclusions}

The data discussed above follows in the footsteps of previous researchers and opens new perspectives in the field.

Nevertheless, the study could not fully avoid some theoretical and methodological flaws.

Firstly, it has already been mentioned that inter-group dynamics are affected by several factors and it is still not fully understood to what extent personal and social levels intersect and interact. Therefore, it cannot be claimed that the offered tentative explanations can offer an exhaustive overview of the psychological processes underling choices made by the participants. A few variables pertaining to the "persona" could not be controlled for practical reasons: levels of empathy, socio-economic status, religion, pre-existing beliefs, just to mention a few. Though the study 
was aimed at investigating social influences in a very specific setting, it must be recognized that the chosen perspective is an important but still partial angle and it should be integrated by other approaches.

Secondly, methodologically speaking, the choice to use vignettes has a solid rationale but also some limitations: it is again a make-believe, and, had the situation happened as depicted in real life, there is no guarantee that students would behave accordingly to the stated opinions. Moreover, even though the instructions were plausible and credible, they might also clash with the "real" experience that students have with that particular teacher, either in the manipulation or in the control group. Some of the students, who failed to identify the manipulation, have clearly understood the wording but chose the option the fitted best with their expectations and former interactions. Being the schools taking part willingly, no real randomization was possible. It was clear by the enthusiasm and the requests of feedback that those schools have already developed a special sensitivity to the topic of inclusion and in many cases they have already set in place policies and pedagogical projects to facilitate it.

These limitations notwithstanding, the results showed that this procedure has a promising applicability to students as young as pre-adolescent. It has a side benefit of being easy to administer and fits well in the overflowing schedule of modern schools. A possible perspective that has not yet been addressed would be to explore cross-cultural differences as a separate variable and in conjunction with teachers' instructions.

\section{Acknowledgements}

The authors appreciate the contributions of Alexander Tatarko in testing the instrument and Maria Bultzeva's assistance with the Ethics application.

The authors would like to thank all the school staff members who relentlessly offered their invaluable help to make data-collection possible. Namely, the Italian Schools of Rozzano (MI), Ravarino (MO), I.C. Briosco (PD) and 1708 (Peredelkino), 1532 (Tepliy Stan), 17 (Konkovo), Karinskaya Srednyaya Shkola (Moscow Region) and Ershovskaya Srednyaya Shkola Named after Vasiliy Fabrichnov (Moscow Region). Through their actions new standards for the future generation are being set.

\section{References}

Aboud, F. E. (2003). The formation of in-group favoritism and out-group prejudice in young children: Are they distinct attitudes? Developmental Psychology, 39(1), 48-60.

Alexandrov, D., Baranova, V., \& Ivaniushina, V. (2012). Migrant children in Russia. Migration, ethnicity and segregation in St. Petersburg (No. SESL WP 001). Saint Petersburg, Russian Federation.

Allport, G. W. (1954). The nature of prejudice. Reading, MA: Addison-Wesley.

Bandura, A. (2000). Exercise of human agency through collective efficacy. Current Directions in Psychological Science, 9(3), 75-78. 
Binder, J., Zagefka, H., Brown, R., Funke, F., Kessler, T., Mummendey, A., ... Leyens, J. P. (2009). Does contact reduce prejudice or does prejudice reduce contact? A longitudinal test of the contact hypothesis among majority and minority groups in three European countries. Journal of Personality and Social Psychology, 96(4), 843-856.

Boyd, R., \& Richerson, P. (1985). Culture and the evolutionary process. Chicago, IL: University of Chicago Press.

Civitillo, S., Schachner, M., Juang L., van de Vijver F. J.R., Handrick A., \& Noack P. (2017). Towards a better understanding of cultural diversity approaches at school: A multi-informant and mixedmethods study. Learning, Culture and Social Interaction, 12, 1-14. doi:10.1016/j.lcsi.2016.09.002

Crisp, R. J., \& Turner, R. N. (2009). Can imagined interactions produce positive perceptions? Reducing prejudice through simulated social contact. American Psychologist, 64(4), 231-240.

Eller, A., \& Abrams, D. (2004). Come together: Longitudinal comparisons of Pettigrew's reformulated intergroup contact model and the common ingroup identity model in Anglo-French and MexicanAmerican contexts. European Journal of Social Psychology, 34(3), 229-256.

Fallona, C. (2000). Manner in teaching: a study in observing and interpreting teachers' moral virtues. Teaching and Teacher Education, 16(7), 681-695.

Hughes, J. N., Cavell, T. A., \& Willson, V. (2001). Further support for the developmental significance of the quality of the teacher-student relationship. Journal of School Psychology, 39(4), 289-301. doi:10.1016/S0022-4405(01)00074-7

Keene, E. O., \& Zimmermann, S. (2013). Years later, comprehension strategies still at work. The Reading Teacher, 66(8), 601-606.

Losin, E. A. R., Woo, C. W., Krishnan, A., Wager, T. D., Iacoboni, M., \& Dapretto, M. (2015). Brain and psychological mediators of imitation: sociocultural versus physical traits. Culture and Brain, 3(2), 93-111.

Montague, M., Krawec, J., Enders, C., \& Dietz, S. (2014). The effects of cognitive strategy instruction on math problem solving of middle-school students of varying ability. Journal of Educational Psychology, 106(2), 469-481.

Murray, C., \& Greenberg, M. T. (2000). Children's relationship with teachers and bonds with school an investigation of patterns and correlates in middle childhood. Journal of School Psychology, 38(5), 423-445.

Nesdale, D. (2004). Social identity processes and children's ethnic prejudice. In M. Bennett \& F. Sani (Eds.), The development of the social self (pp. 219-245). New York: Psychology Press.

Pettigrew, T. F. (1998). Intergroup contact theory. Annual Review of Psychology, 49, 65-85.

Pettigrew,T. F., Tropp, L. R., Wagner, U., \& Christ, O. (2011)."Recent advances in intergroup contact theory. International Journal of Intercultural Relations, 35(3), 271-280.

Robbins, J. M., \& Krueger, J. I. (2005). Social projection to ingroups and outgroups: A review and meta-analysis. Personality and Social Psychology Revier, 9(1), 32-47.

Schachner, M. K., Noack, P., Van de Vijver, F. J. R., \& Eckstein, K. (2016). Cultural diversity climate and psychological adjustment at school - equality and inclusion versus cultural pluralism. Child Development, 87(4), 1175-1191.

Stephan, W. G., \& Stephan, C. W. (2000). An integrated threat theory of prejudice. In S. Oskamp (Ed.), Reducing prejudice and discrimination (pp. 23-45). Mahwah, NJ: Lawrence Erlbaum Associates.

Stephan, W. G., \& Stephan, C. W. (2001). Improving intergroup relations. Thousand Oaks, CA: Sage Publications, Inc. 
Thijs, J., \& Verkuyten, M. (2016). Ethnic attitudes and social projection in the classroom. Child Development, 87(5), 1452-1465.

Thomas, D. E., Bierman, K. L., Powers, C. J., \& Conduct Problems Prevention Research Group. (2011). The influence of classroom aggression and classroom climate on aggressive-disruptive behavior. Child Development, 82(3), 751-757.

Turner, J. C., Hogg, M. A., Oakes, P. J., Reicher, S. D., \& Wetherell, M. S. (1987). Rediscovering the social group: A self-categorization theory. Oxford, UK: Basil Blackwell

Van Oudenhoven, J. P., Blank, T. D. S., Leemhuis, F., Pomp, M., \& Sluis, A. F. (2008). Nederland deugd [Dutch virtue]. Assen, The Netherlands: Van Gorcum. (in Dutch)

Verkuyten, M., \& Masson, K. (1995). 'New racism', self-esteem, and ethnic relations among minority and majority youth in the Netherlands. Social Behavior and Personality: An International Journal, 23(2), 137-154.

Wright, S. C., Aron, A., McLaughlin-Volpe, T., \& Ropp, S. A. (1997). The extended contact effect: Knowledge of cross-group friendships and prejudice. Journal of Personality and Social Psychology, 73(1), 73-90.

Lucia Bombieri - research intern, International Scientific-Educational Laboratory for SocioCultural Research, Expert Institute; Ph.D. student, Faculty of Social Sciences, School of Psychology, National Research University Higher School of Economics.

Research area: cross-cultural psychology, developmental psychology, educational psychology, the role of teachers in education.

E-mail: lbombieri@hse.ru

Victoria N. Galyapina - leading research fellow, International Scientific-Educational Laboratory for Socio-Cultural Research, Expert Institute; associate professor, Faculty of Social Sciences, School of Psychology, National Research University Higher School of Economics, Ph.D.

Research area: cross-cultural psychology, intercultural relations, values and norms, identity.

E-mail: vgalyapina@hse.ru

Ekaterina V. Bushina - senior research fellow, International Scientific-Educational Laboratory for Socio-Cultural Research, Expert Institute; associate professor, Faculty of Social Sciences, School of Psychology, National Research University Higher School of Economics, Ph.D.

Research area: cross-cultural psychology, cross-cultural relations, values, creativity, attitudes toward innovations.

E-mail: evbushina@hse.ru 


\title{
Эффективность влияния учителей на изменение отношения учащихся к мигрантам: исследование в Италии и России
}

\author{
Л. Бомбиери ${ }^{\text {a }, ~ В . Н . ~ Г а л я п и н а ~}{ }^{a}$, Е.В. Бушина \\ ${ }^{a}$ Национальный исследовательский университет «Высшая школа экономики», 101000, Россия, \\ Москва, ул. Мясницкая, д. 20
}

\section{Резюме}

Рост мигрантов ведет к увеличению числа детей с мигрантским прошлым, живущих в странах, которые не являются их родиной. Такие дети часто сталкиваются с большими трудностями при социализации в новых условиях. Одной из важнейших сфер взаимодействия принимающего населения и мигрантов является обучение в школе. В этом исследовании мы рассмотрели, как различные типы инструкций учителей (просоциальные и поведенческие) влияют на отношения и убеждения школьников по отношению к сверстникам с мигрантским опытом. Исследование проводилось среди школьников (средний возраст 11 лет) в двух странах: в Италии $(\mathrm{N}=93)$ и в России $(\mathrm{N}=134)$. В экспериментальных группах учитель давал просоциальную инструкцию перед началом основного исследования, в контрольной - поведенческую. Получив эту рекомендацию, ученики читали вымышленный сценарий, в котором потенциальный одноклассник из неустановленного иностранного государства, со своими культурными особенностями, должен был присоединиться к обучению в этом классе. Ответы были измерены с помощью пяти шкал оценки приятности новенького, положительных и отрицательных отношений к участникам ин-группы и группы друзей новенького (аутгруппы). На индивидуальном уровне результаты подтверждают, что просоциальные инструкции формируют положительные установки к новичку, увеличивают благоприятные установки и препятствуют формированию отрицательных установок по отношению к своей и чужой группам. Значимые различия были обнаружены при сравнении двух условий. Так, благоприятные характеристики были более выраженными в про-социальной группе, чем в поведенческой. К тому же отрицательные черты, по отношению к ингруппе и аутгруппе, в просоциальной группе значимо ниже. В работе обсуждаются последствия этих результатов в отношении влияния учителей в моделировании социальных навыков и развития социальных процессов в контексте школьного образования.

Ключевые слова: отношение к мигрантам, новенький, просоциальные и поведенческие инструкции, отношение к своей и внешним группам.

Бомбиери Лучия - аспирант, департамент психологии, факультет социальных наук; стажер-исследователь, Международная научно-учебная лаборатория социокультурных исследований, Экспертный институт, Национальный исследовательский университет «Высшая школа экономики».

Сфера научных интересов: кросс-культурная психология, психология развития, психология образования, роль учителя в образовании.

Контакты: lbombieri@hse.ru 
Галяпина Виктория Николаевна - ведущий научный сотрудник, Международная научноучебная лаборатория социокультурных исследований, Экспертный институт; доцент, департамент психологии, факультет социальных наук, Национальный исследовательский университет «Высшая школа экономики», кандидат психологических наук, доцент.

Сфера научных интересов: кросс-культурная психология, межкультурные отношения, ценности и нормы, идентичность.

Контакты: vgalyapina@hse.ru

Бушина Екатерина Валерьевна - старший научный сотрудник, Международная научноучебная лаборатория социокультурных исследований, Экспертный институт; доцент, департамент психологии, факультет социальных наук, Национальный исследовательский университет «Высшая школа экономики», кандидат психологических наук, доцент.

Сфера научных интересов: кросс-культурная психология, межкультурные отношения, ценности, креативность, отношение к инновациям.

Контакты: evbushina@hse.ru 